\title{
The Socio-economic Importance of an Ecolodge as a Tool for Sustainable Tourism: A Study of Obudu Mountain and Resort, Becheeve Community, Cross River State, Nigeria
}

\section{Ojo Idowu}

Department of Tourism and Hospitality Management, Elizade University, Ilara-Mokin, Nigeria

\section{Email address:}

idowuojo1912@gmail.com

\section{To cite this article:}

Ojo Idowu. The Socio-economic Importance of an Ecolodge as a Tool for Sustainable Tourism: A Study of Obudu Mountain and Resort, Becheeve Community, Cross River State, Nigeria. International Journal of Sustainable Development Research.

Vol. 7, No. 2, 2021, pp. 41-49. doi: 10.11648/j.ijsdr.20210702.12

Received: May 11, 2021; Accepted: May 29, 2021; Published: July 24, 2021

\begin{abstract}
Ecotourism's achievements and the opportunities it brings to the hosts' society should never be underlined by Ecolodge operations in ecotourism destinations. Conservations have turned more and more towards ecotourism as an Ecolodge operates to provide the local residents both social and economic benefits while protecting cultural and environmental heritage. The aim of this analysis is to ascertain the benefits of Ecolodge to the host community, the level of involvement of the local residents in the Ecolodge's management, and their functions in the protection and conservation of their cultural heritage and natural resources. Data were produced using the survey research design and well-structured questionnaire. Routine sampled respondents consisting of household heads, families and residents, of the community of Becheeve, Obankilu, Cross River State and the community of Host Obudu Mountain and Resort received around 400 questionnaires. The results produced were evaluated based on their degree of approval of the indices used to calculate the effect of Ecolodge, using percentages. The results were shown. The survey's findings showed that the Ecolodge provided tremendous socio-economic benefits to local communities, as well as that members of the community were actively involved in the maintenance of the Ecolodge and the protection of their cultural heritage in the study region. The report recommended community awareness program, government intervention in the provision of amenities, public and private partnership initiative, more investment on Ecolodge among others for improvement of operations and sustaining tourism in the study region and throughout the country.
\end{abstract}

Keywords: Ecolodge, Ecotourism, Socio-economic Benefits, Community Participation, Cultural and Environmental Conservation

\section{Introduction}

Tourism is a primary source of revenue and an important mechanism for boosting the economies of some developing countries. It can be regarded as a significant source of foreign currency and also a significant means of direct and indirect employment for the people in the host community. Importantly, an effort to promote tourism on the other hand in some regions has produced negative consequences for the environment and the host community. The sustainability theory of tourism growth, according to the literature, the theory consists of three main components which are the generation of economic benefits for the host community and active participation of the host community in development activities; the protection of cultural heritage and; the conservation of environmental resources for future generations [1-5]. Most countries are incorporating a sustainable development policy into their economic development today.

Tourism is linked to long-term sustainability and prosperity. It is an excellent engine and driver of economic wealth formation in developing countries such as the United States, France, and Germany. Several countries like the United States, the United Kingdom, France, Israel, Greece, Lebanon, Italy, and Thailand, to name a few. Seychelles, Mauritius, Bahamas, Fiji, Philippines, and Egypt are now reaping the benefits of their investments in renewable energy.

Tourism is an activity that is increasingly expanding all 
over the world. The tourist industry and center have both added to revenue generation. Integration, foreign exchange, rural entrepreneurship, promotes development, and work facilitation is all important in urban areas, as well as for rural residents. Tourism will help developed countries around the world, such as Nigeria, collect money. Rather than focusing solely on crude oil sales to move the economy ahead, this is inadequate in the whole planet [6].

Hospitality and Tourism sector is one of the most significant aspects today, and it is expanding fast all over the global economy. People working in this area, on the one hand, are often ignorant about the world they are exploiting in order to maximize greater economic benefits from tourism, and abuse and improper use of natural and social resources, mainly in developing nations, are prevalent challenges. There seem to be continual difficulties as many businesses and organizations, mostly from more industrialized economies, enter these poorer markets with alarming speed when prices are lower and it is easier to manipulate laws and policies. Unfortunately, cases of unsustainable use of physical and anthropogenic resources are common, mostly to the detriment of the native community and economy [7].

People are becoming more informed and concerned about challenges such as deforestation, natural resource exploitation, social well-being, and so on, and the value of sustainable tourism delivery is increasing. Furthermore, travelers seem to be more aware of these issues, and the need for more responsible travel is frequently being identified [8]. The critical component of nature in sustaining human wellbeing is also winning more ground in the sense of broader sustainable development. Mankind's wealth - habitats, genetic energy, and species - should be the bedrock of a green economy, i.e. an economy that ultimately improves well-being and economic activism while reducing environmental threats and ecological resource shortages [9]. Existence encompasses the very operation of our socioeconomic processes, offers a diverse range of market possibilities, and provides cost-effective solutions for different markets. The understanding that environmental resources is critical to our well-being and should be regarded for its many benefits means that sustainable use, preservation, and protection of natural should play a critical role in the growth of more prevailing market [10].

The aim of this study is to determine the socioeconomic benefits of Eco-lodge operations to local residents, as well as to highlight their involvement in Ecolodge management and the steps they are taking to protect nature and environmental resources as a tool for sustainable tourism in Nigeria.

Research Objective and Questions

The objectives of the study are:

1) To determine the economic and social benefits of ecolodge to host communities.

2) To know the level of participation of the local people in ecolodge management.

3) To identify the roles of the local people in the preservation of their cultural heritage and environmental resources.
The study intends to tackle the following research questions in line with the above stated objectives, these research questions are:

1) Is the ecolodge providing any economic or social benefits to the host community's people?

2) Is there any effective participation of the host community in the management of ecolodge?

3) What are the roles of the local people in the preservation of their cultural heritage and environmental resources?

\section{Review of Literature}

\section{The Concept of Ecolodge}

Ecolodge is a kind of eco-hotel. The hotel, otherwise regarded as a high sierra, emerged in Africa and was a form of traveler lodging made of wood or fabric and situated at the heart of a wildlife reserve or natural park. The interest in attaching the particle eco for ecological to the term lodge stems from the relationship between this type of accommodation and its anchoring on protected sites [11]. This theory was originated in the $1990 \mathrm{~s}$ to define an ecosystem type that is distinct from others in terms of how it was constructed or managed. Since then, there have been several different perspectives and opinions about what defines the right to use the term "eco" [11].

The International Ecolodge Guidelines was written by Hitesh Mehta, an architect and leading member of the International Tourism Society, in 1999, these guidelines are states that a typical ecolodge accommodation must contribute to the three basic concepts of ecotourism [28], which are:

1) It has to be centered on a rural setting;

2) Be of benefit to the local residents and;

3) Facilitate public awareness and education campaigns.

There are certain standard and criteria that an ecolodge is expected to meet [12]. Some of these standards and criteria are:

1) Spacious rooms and good artistic drawing or historical artifacts that depict the location of the ecolodge.

2) The settings of an ecolodge should be in a natural environment that has been meticulously preserved and cultured.

3) Use of ecologically acceptable building materials for construction and interiors.

4) Ensure it makes use alternative energy, water and waste collection methods that are environmentally friendly and sustainable.

5) Have a great cooperation with the local population and contribute to a sustainable development for the local community.

6) Organize ecologic educational programs for tourist and also the employees at the ecolodge.

Environmentally Sustainable Practices

Global standard give priority to high-quality green spaces and other sustainable measures that are strategically and carefully planned and deliver conserve wildlife, environmental resources, while also providing a wide variety 
of benefits and amenities to the local residence. A natural and super habitat which features green spaces in rural and urban, terrestrial, inland, maritime, and marine areas are also included in Green Infrastructure which are said to be incomplete without these protected areas [13]. This therefore means that ecolodge management is responsible for maintaining sustainable infrastructure.

\section{Sustainability and Sustainable Tourism}

Environmental resources and cultural heritage should be properly protected and preserved for the future generations; this is a collective effort which should be championed by the host community alongside the government and private partnership, the essence of this is that the local residents tend to benefit more than anyone else, it is their heritage, and are considered the major stakeholders as far as Ecolodge or Ecotourism is concerned. The increasing consequences of overpopulation remain a criterion to help us maintain our potential policy. People transportation remains a serious environmental problem as a result of an uncontrollable population. Besides this, human resource exploitation and environmental factors have become increasingly critical and challenging in recent years, and one of our century's greatest priorities is to pursue sustainable growth. The definition of sustainability refers to the preservation of our heritage for future generations, as well as the protection of our natural resources from all kinds of over-exploitation. The key focus of sustainability is on the health of better future, especially with regard to extremely valuable natural resources, rather than on meeting immediate needs. Environmental sustainability is described as "development that meets current needs without jeopardizing future generations' ability to fulfill their current demands" Where 'necessitates' refers to the most specific requirements that must be taken into account, and it is important to remember that sustainability is regarded as a long time objective.

The idea of preserving our heritage beyond instant gratification is but once; it was born out of the predominant purpose of transmitting on to the next era. Since the concept is new, the lot of scholars, research studies, and outcomes is incredibly varied; social, economic, and environmental aspects can be considered a basic foundations establishing this ideology; however, as mentioned in [14] (ecological, social, economic, cultural, political) based on the philosophical program. The concept of sustainability has three main definitions: (a) By not using of quasi resources faster than green alternatives can be provided for them (b) By not using renewable energy sources quicker once they've been consumed (c) By not generating substances rapidly than the biosphere can be accomplished [15].

Sustainable tourism emphasized the for local participation of all relevant stakeholders, as well as strong political leadership to ensure wider participation and consensus building through some constitutional inclinations as either a result, to do this, it is important to track effects and implement appropriate preventive and/or necessary actions as required [16]. Actually, more than three-quarters of corporations (77 percent) have measures in place to reduce their ecological consequences. Environmentally sustainable activities are most common in Australasian and North American enterprises (both 84 percent vs. 77 percent overall), while they are least common in European properties (73 percent). The tourism sector in the EU contributes nearly 3\% of GDP, with about 1,8 million companies operating about 5\% of the total workforce (approximately 11,3 million jobs). As related industries are taken into account, tourism's total contribution to GDP creation is even higher; tourism effectively produces about $10 \%$ of EU GDP and employs about $11 \%$ of the workforce. Tourism is responsible for $5 \%$ of environmental impact, with 4 percent contributing to shipping, close to $1 \%$ to lodging, and a limited portion to other tourism operations [17].

Based on the duration of stay, hotel size and facilities, nature and quantity of food eaten, and other factors, a visitor uses between 84 and 2,000 liters of water each day. The world's 32,000+ golf courses irrigate their greens with an average 9.5 billion liters of water every day and this is also applicable in Spain where a typical golf course uses the same amount of water in a town of 12,000 inhabitants [18]. Enterprises should be committed to protecting the natural environment, according to $70 \%$ of residents, and acceptable working practices are desired by $55 \%$ [19].

Socio-economic Benefits

The concept 'benefit' is used in the broadest sense to refer to the socio-economic values of ecology (i.e. biodiversity and ecosystems), to use both economic and larger social benefits, and to use the worth measurement for empirical, measurable, and financial information. In certain cases, categorizing or creating a monetary measure for an established ecosystem service is not feasible or indeed practicable. This is true, for example, in many cultural resources. Though considered essential in and of itself, nature provides a variety of benefits, referred to as ecosystem services, which power the global economy and underpin human and social well-being [10]. Sustainable natural cycles, for example, regulate our climate, fertilize our crops, prevent soil erosion, and protect us from natural disasters.

\section{Contribution of Ecosystem to Human Sustainability}

Nature and human welfare are largely interrelated, with habitats and ecology supplying our communities with crucial resources, i.e. so-called environmental services. Nature and ecology also have inherent worth of their own way, in addition to such anthropocentric advantages. It's worth defending, that is, the climate transition triggered by property, however, the use and wasteful exploitation of natural resources leads to degradation of forests and their resources, followed by declining habitats and services with numbers and growing species extinctions [20].

Generally speaking, economic stability is heavily dependent on the distribution of four types of capital services: man-made, individual, natural and social. All-natural [21]. The significance of natural capital as a development factor, including biological resources and ecosystem services, if it preserves and also extends our options for balanced economic growth and sustainability, it should not be ignored. In other words, the amount of industries that benefit from ecosystem services accounts for a much greater share of the 
economy than many appreciate. In the pharmaceutical industry, for example, $26 \%$ of all new medicines licensed.

The Natural Components for the Sustenance of Ecotourism Ecotourism itself are nature-based tourism hence, it requires some natural component for its survival. According to [22], one of the component for sustaining ecotourism is ecology which causes "fluctuation among living organisms from all habitats, particularly, but not limited to, terrestrial, marine, and other aquatic habitats, as well as the biological complexities of which they are a part; this study specifically within organisms, among species, and among populations" and biodiversity is another strong component which help to sustain ecotourism and aid to stabilize the nature, biodiversity is a diverse complex of plant, animal, and microorganism communities, as well as their non-living world, functioning as a cohesive unit," Complex interactions between living (biotic) and non-living (organisms) components (reserves), sunlight, climate, water, minerals, and nutrients, define every ecosystem. The abundance and diversity of biodiversity play a significant role as well. The benefits that humans get from biodiversity are referred to as ecological services.

The Millennium Ecosystem Assessment recognizes the following major groups of ecosystem services that benefit humans:

a. Lifecycle management utilities - ecosystem-derived goods (e.g. food, fibre, fuel, water).

b. Governing utilities - the advantages of ecosystem systems (e.g. climate, floods, disease, waste and water quality).

c. Environmental resources - the intangible advantages that people derive from environments (e.g. recreation, tourism, aesthetic, spiritual and ethical values).

d. Ecology services and processes that are needed for the creation of all other natural ecosystems (originally known as making provision) (for example, soil fertility, photosynthetic activity, and biogeochemical cycles).

In addition to the above definition, habitat services should be identified as a distinct type of ecological services to emphasize the role of environments in energy security for threatened species (e.g., as garden centers) and as seed stream "guards" (preserving inbreeding variability and resilience) [23]. Environment tolerance relates to habitats' ability to deal with disruptions without going into a substantially different condition, such as disrupting ecosystem service provisioning. It is thought that conservation improves an environment's sustainability. In sustaining ecotourism and environmental stability, physical resources play some prominent roles in term of its supplies of both economic, biological and physical resources present to the Earth, as well as ecosystem services [10]. Ecosystem services flow from "natural capital stocks" in the same way as interest or dividends flow from stocks and bonds, to use an economic metaphor.

Assets and Distribution of Environmental Resources also contribute immensely to the sustenance of Ecotourism, this is the ability of environments to provide rewards and the flow of concrete benefits to humans. The size of the flow will vary from national to worldwide. For instance, economic impacts from photosynthesis are observed on a local basis even while promoting food production at the global scale. An atmosphere that is depleted has a decreased supply of resources, and the flow of benefits is smaller as a consequence. While, environmental resources through a system of high-quality nature reserves and other sustainable amenities that are carefully built and delivered to conserve wildlife whilst also providing a lot of positive effects and benefits to Ecotourism. Wild and semi-natural habitats, features, and natural areas in rural and urban, rural, aquatic, coastal, and underwater areas are also included in Sustainable Development. Environmental Sustainability is thought to be incomplete without protected areas [13].

Conservation and Sustainability

Nature's vital role in maintaining human well-being is also gaining ground as a result of increased environmental change. Mankind's wealth, biodiversity, natural capital, and animals, in general, may serve as the foundation for a sustainable economy, which promotes human well-being and economic activism while significantly reducing environmental challenges and ecological scarcity [9]. Accepting that mineral wealth is critical to our and should also be valued for its many benefits means that sustainable utilization, preservation, and protection of the environment must perform a significant role in the development of more prevailing market [10].

The promotion of conservation and sustainability are easily practicable most especially when individual in the community are well informed through public campaign, whereas, the idea is to preserve and protect the community common wealth for present and future use [24].

Encouraging awareness program among the local residents on the need to protect their cultural heritage and the environmental resources should be an interval discussion and consensus, having considering the benefits they are deriving from the resources. However, such enlightenment program would go a long way to enhance the efficient use of environmental resources and thereby prompting sustainable economy [24]. In another dimension, sharing consumption are oftentimes help to mitigate the negative impact of environmental hazards since everyone has a role to play [2526]. In essence, sharing of resources can be regarded as a tool of ensuring environmentally usage of community resources for the benefit of all.

\section{Methodology}

The study centered on the socio-economic impacts of the Ecolodge in Obudu Mountain and Resorts, which is situated in Becheeve, Cross River State's Obanliku Local Government Area. The survey test design was used in this analysis. A well-structured questionnaire was distributed to 400 (but only 327 were retrieved) randomly selected survey respondents, including heads of households, relatives, and residents of Utanga, Ugbakoko, Amana, Keyi, and Imale in Becheeve. The results were evaluated using percentages to measure the data depending on their degree of approval of 
Ecolodge's impacts.

Study Area

Through 1951, M McCaughley [27], was the first one to traverse the mountains, founded the Obudu Mountain Resort, traditionally known as the Obudu Ranch. It is one of Nigeria's most delightful and exciting tourist destinations. It is situated on the Obudu Plateau, that provides you a great scenery of the entire landscape with fresh mountain air. In the northeast part of the county of Cross River, near the Cameroon frontier. This destination center has developed into a major tourist attraction. The scenery and peaceful atmosphere are attractive, and the heavens wave through its hills and troughs. Tourists will enjoy a nice combination of warm and cold climate because the atmosphere is very cool. Houses, eco-houses, regular quarters, executive office, hütten and presidential suites are included in Obudu Mountain Resort rooms. The Mountain Resort of Obudu is located at 1576 meters' altitude. One should either navigate from the base of the hill on this iconic revolving $11 \mathrm{~km}$ road or take the ferris wheel. It requires approximately 25 minutes to drive and about 6 minutes to navigate the ferris wheel. The region encompasses moderately temperature because of its 1580 meters high from the sea level. The environment is ideal for visitors' pleasure.

Obudu Mountain and Resort is located at Becheeve community which is one of the ten political wards that made up of Obanliku Local Government in Cross River State within the Northern district of Cross River State popularly known as Ogoja. It has an area of 1,057 kmsquare and a population of 110,324 in 2006 population census and it is projected to be estimated at 156,557 in 2020 with 17 tribes. The major occupation of Becheeve community is farming and trading of market products.

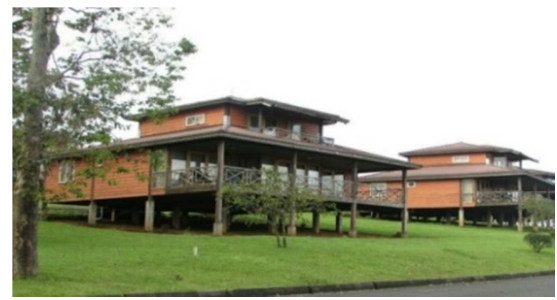

Figure 1. Showing Ecolodge of Obudu mountain and Resort.

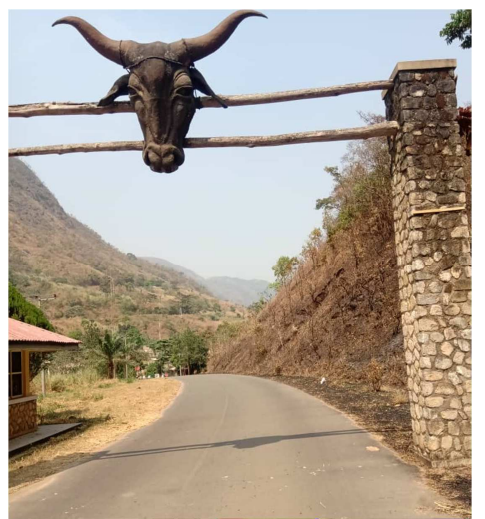

Figure 2. Showing the entrance of Obudu mountain and resorts.

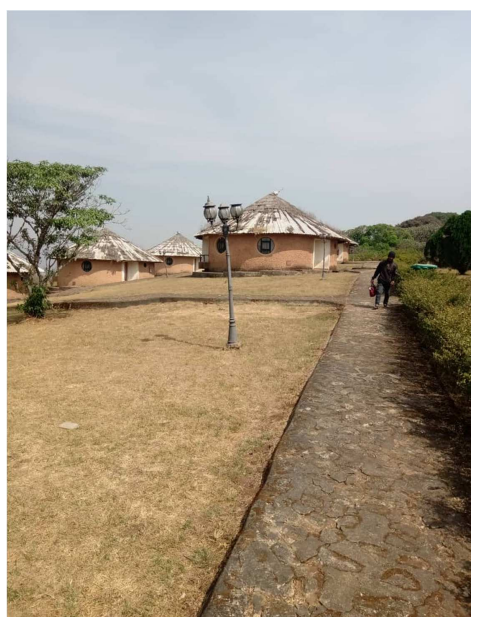

Figure 3. Showing Ecolodge in Obudu Mountain and Resorts.

\section{Data Analysis and Discussion}

The findings from the study are presented as follows; [a] Sex of Respondents

Table 1. Sex of respondents.

\begin{tabular}{lll}
\hline Sex & Frequency & Percentage (\%) \\
\hline Male & 173 & 52.9 \\
Female & 154 & 47.1 \\
Total & 327 & 100 \\
\hline
\end{tabular}

Source: Author's fieldwork, 2021

From the field survey in Becheeve community in Obudu mountain and resorts Ecolodge, there were more males' respondent than female. Table 1 show that male respondents constituted $52.9 \%$, while the female respondents accounted for $47.1 \%$. Findings revealed that males are the majority heads and owners of households in Becheeve community.

[b] Age of Respondents

Table 2. Age of Respondents.

\begin{tabular}{lll}
\hline Age & Frequency & Percentages (\%) \\
\hline $18-28$ & 50 & 15.3 \\
$29-39$ & 72 & 22 \\
$30-40$ & 127 & 38.8 \\
$41-51$ & 44 & 13.5 \\
51 and above & 34 & 10.4 \\
TOTAL & 327 & 100 \\
\hline
\end{tabular}

Source: Author's fieldwork, 2021

The age distribution on the survey conducted at Becheeve community on Obudu Mountain and resorts indicated that age bracket between 30-40 years were the highest respondents with $38.8 \%$. This trends can be attributed to the enlightenment and youthfulness with the vigor to made their decision known. In a similar trend, the age bracket of 29-39 followed with $22 \%$, this is yet a youthful age, while $18-28$ years' age bracket of the respondents recorded $15.3 \%$, age bracket of $41-51$ years had $13.5 \%$ of the respondents and finally, the age bracket 51 years and above which is the aged 
group recorded the lowest respondents with $10.4 \%$.

This result clearly showed that majority youth in the Becheeve community of Obudu Mountain and Resorts were either participating in Ecolodge management or benefiting from Ecolodge operations in the community.

[c] Religion of Respondents

Table 3. Religion of the respondents.

\begin{tabular}{lll}
\hline Religion & Frequency & Percentages (\%) \\
\hline Christianity & 114 & 34.9 \\
Muslims & 28 & 8.6 \\
Traditional & 180 & 55 \\
Others & 5 & 1.5 \\
TOTAL & 327 & 100 \\
\hline
\end{tabular}

Source: Author's fieldwork, 2021

Findings suggested that majority of the respondents in Becheeve community of Obudu Mountain and Resorts are predominantly traditional worshippers with a total percentage of $55 \%$ followed by the Christian respondents of $34.9 \%$, while Muslims respondents were just $8.6 \%$ and other religion had the lowest figure with $1.5 \%$.

The figures here shown that the people of Becheeve community prioritize their traditional religion to other forms of religion thereby preserving/conserving their cultural heritage.

[d] Occupation of Respondents

Table 4. Occupation of respondents.

\begin{tabular}{lll}
\hline Occupation & Frequency & Percentages (\%) \\
\hline Civil servants & 50 & 15.3 \\
Farming & 112 & 34.3 \\
Trading activities & 76 & 23.2 \\
Artisans & 89 & 27.2 \\
TOTAL & 327 & 100 \\
\hline
\end{tabular}

Source: Author's fieldwork, 2021

Table 4 shows that farming is the predominant occupation of the people of Becheeve community of Obudu Mountain and Resorts with about $34.3 \%$ of the people engaged in farming. Artisans constituted $27.2 \%$ while trading activities generally represents $23.2 \%$ of the occupation. Trading activities in this regard is concerned with selling of agricultural products, provision and petty goods while $15.3 \%$ are Civil Servant.

The socio-economic Importance of Ecolodge to the Host Community

Table 5. The socio-economic importance of ecolodge to the host community.

\begin{tabular}{lll}
\hline The socio-economic importance of Ecolodge to the host community. & Frequency & Percentage (\%) \\
\hline The creation of employment for the teeming youth in the local people & 120 & 36.7 \\
Improvement of the standard of living of the local people as a result of commercial activities & 68 & 55 \\
The creation of new connection and friendliness & 13 & 20.8 \\
Improvement of value sharing between the local people and the tourist & 28 & 15 \\
Enhancement of National and International recognition & 5.9 \\
Increase in Population of the community & 12 & 8.6 \\
Attraction of government attention in the provision of social amenities. & 12 \\
Community as a center of attraction to investors as a result of tourist influx. & 11 \\
Generation of revenue to the local government. & 327 \\
TOTAL & 3.7 & 3.4 \\
\hline
\end{tabular}

Source: Author's fieldwork, 2021.

The table 5 showing the result of the survey on the socioeconomic importance of ecolodge to the Becheeve community of Obudu Mountain and Resorts. The finding shows that there was significant economic development on the people of the community through employment which indicated $36.7 \%$ of the respondents and there was also a great improvement on the standard of living of the people in the study area as findings show that $20.8 \%$ of the respondents agreed based on the commercial activities that sprung up in the community.

Finding in the survey shown clearly as $16.8 \%$ respondents indicated that there was a social benefit to the community through the creation of new connection and friendliness between the host community and the tourists, there was enhancement of National and International recognition based on $8.6 \%$ respondents, and $4.6 \%$ respondent agreed that tourist who patronize the ecolodge contributed to their population. Improvement of value sharing between the local people and the tourist as indicated by $3.9 \%$ respondents followed by $3.7 \%$ respondents who claimed that the community had become a center of attraction to investors thus finding reveals some small scale businesses like POS ventures, transportation businesses, and other ancillary services to support the ecolodge operations. 3.4\% respondents for the generation of revenue to the local government and finally, the survey shown that there is little or no government attention in providing social amenities like good road, health care centers, school and other essential infrastructures as pastry $1.5 \%$ respondents claimed. In essence, further findings show that majority of the local people were gainfully employed by the Ecolodge operators.

The Level of Local People Participation in Ecolodge Management 
Table 6. Community participation in Ecolodge management.

\begin{tabular}{lll}
\hline Community participation in Ecolodge Management & Frequency & Percentage (\%) \\
\hline Participation in siting an Ecolodge & 36 & 11 \\
Participation in the design of the Ecolodge & 10 & 3.1 \\
Participation in the waste management & 30 & 9.2 \\
Participation in the decision making process & 39 & 11.9 \\
Participation in the general administration of the Ecolodge & 32 & 9.8 \\
Participation in the recruitment of staff of Ecologe and taking of employment opportunity & 45 & 13.8 \\
Contribution to the protection and safety of the Ecolodge amenities & 33 & 10 \\
Interpretation of local languages to the tourist & 37 & 11.3 \\
Participation on the maintenance of law and order & 31 & 9.5 \\
Participation in the preservation of customs, norms and traditions & 34 & 10.4 \\
Total & 327 & 100 \\
\hline
\end{tabular}

Source: Author's fieldwork, 2021

Table 6 showing the participation of the local community on the management of Ecologe. The survey conducted shown clearly that host community participate squarely and fairly on the management of Ecolodge in Becheeve community of Obudu Mountain and Resorts. For instance, $13.8 \%$ of the respondents indicated that local people are majorly participating in the recruitment of staff and taking of employment opportunities more than every other aspect of management, this was followed by $11.9 \%$ respondents on the participation of the local people in the decision making of Ecolodge operations.

However, 11.3 respondents justified the participation of the local people on the language interpretation while $11 \%$ respondents suggested that local people were involved on the siting of Ecolodge. Meanwhile, $10.4 \%$ respondents were engaged on the preservation of their customs, norms and traditions and $10 \%$ respondents claimed that local people also helped to protect Ecolodge amenities, 9.8\% respondents indicated that local people participated in the general administration of the Ecolodge and 9.5\% respondents opined that local people participated in the maintenance of law and order.

The survey also unveiled as indicated by $9.2 \%$ respondents that local people did participated on the waste disposal management and finally $3.1 \%$ claimed that local people participated in the designing of the Ecolodge. The finding in Becheeve community of Obudu mountain and Resorts indicated that there was minimal participation of the local people in the designing of Ecolodge and this may be attributed to the little or no knowledge of science and technology by the local people.

The Preservation of Cultural Heritage and Environmental Resources

Table 7. Preservation of cultural heritage and environmental resources.

\begin{tabular}{lll}
\hline Preservation of cultural heritage and environmental resources & Frequency & Percentage (\%) \\
\hline The reduction in the consumption of energy and other resources & 30 & 9.2 \\
The upholding of customs, norms and traditional values & 34 & 10.4 \\
The reduction of anthropogenic activities within the host community & 15 & 4.6 \\
Disallowing of business activities that have negative impacts on the environment & 20 & 6.1 \\
Maintenance of natural element without modification & 36 & 11 \\
Regulation and sustenance of carrying capacity of the ecolodge & 65 & 19.9 \\
Regulation of the exploration of environmental resources & 28 & 8.6 \\
Banning of all forms of pollution (air, water and soil) & 31 & 9.5 \\
Encouragement of recycling water in the ecolodge & 35 & 10.7 \\
Increased awareness of environmental programs on the efficient uses of resources. & 33 & 10 \\
Total & 327 & 100 \\
\hline
\end{tabular}

Table 7 showing the preservation of cultural heritage and environmental resources. Findings from the study shows that local people were participating in the management of Ecolodge to preserve their cultural heritage and environmental resources. From the information gathered, survey shows that $19.9 \%$ of the respondents were actively involved in the regulation and sustenance of carrying capacity of the ecolodge in order to check abuse by the tourists. In a similar way, $11 \%$ respondents indicated that maintenance of natural element without modification were part of the measures to preserve their cultural heritage and environmental resources by the community members. 10.4 respondents participated to uphold their customs, norms and traditions while $10 \%$ respondents maintained that community members participated to increased awareness of environmental programs on the efficient uses of resources.

Meanwhile, 9.5\% respondents stressed that local people participated by banning of all forms of pollution (air, water and soil), and $9.2 \%$ respondents opined that the members of the community participated in the ecolodge management to reduce the consumption of energy and other resources. However, $8.6 \%$ respondents indicated that local people participated in the Regulation of the exploration of environmental resources. In a sharp contrast, $6.1 \%$ 
respondents claimed that local people participated to disallowed of business activities that have negative impacts on the environment and $4.6 \%$ respondents stated that local people participated in the reduction of anthropogenic activities within the host community.

The findings show that community people were participating majorly to protect, preserve and conserve their cultural heritage and environmental resources in the course of participating on the ecolodge operations and management but with minimal or little efforts in disallowing business activities that have negative impacts on the environment due to their predominant farming activities thus this remain the same reasons the local people were unable to participate maximally on the regulation of the exploration of environmental resources.

The survey finding suggested that the people rely on faming activities to survive thereby inhibiting them to make a regulation that could stop business activities that are hampering and injurious to environmental resources and other forms of anthropogenic activities which pose enormous threats to our environmental resources, plants and animals including human beings.

\section{Conclusion and Recommendation}

\section{Conclusion}

Ecolodge is a form of accommodation operations that is provided for Tourists at Ecotourism Destinations. It is a nature-based types of accommodation which is aim at mitigating environmental impacts, promote tourism activities, sustain our cultural heritage for future generation. However, Ecolodge operations have enormous impacts to the host community where they are located or established. The study in Becheeve community in Obanliku Local Government, Cross River State where Obudu Mountain and Rosort are situated, indicated that Ecolodge's socio-economic impacts are range from job opportunities that leads to the increase in the living standards of individuals, way to connect with, and friendliness, to boosting small enterprises as POSs, transports, etc. Local and international appreciation of the Beecheeve Group resulted in the ecological operations at Obudu Mountain and Resort. Meanwhile, Ecolodge operations had also brought a great potential to generate foreign exchange, revenue for the government of nations and its serve as additional income and employment for residents in the host community.

Practicing Ecolodge had offered the residents of the community to participate fully on the decision making and the management processes and activities. Local people do participate from the siting of Ecolodge, recruitment and taking of job opportunities among other management activities. Finally, Ecolodge practice had helped the residents of the local community to participate on the preservation of their cultural heritage and environmental resources by safeguarding their norms, customs and traditions, interpretation of languages to the tourist, making of rules and regulation that will conserve the environmental resources of the community.
In conclusion, Ecolodge practices are meant to promote Tourism activities, thus Tourism has the power of attracting direct investors necessary to create jobs, and turning around the socio-economic activities of any nation to enviable State and Nigeria in this regard.

\section{Recommendation}

Base on the survey in the Becheeve Community of Obudu Mountain and Resorts, findings prompt me to recommend the following;

(a) Government: Government at all level are encouraged to provide basic amenities in Becheeve community where Obudu Mountain and Resort is Located. Amenities like portable water, schools, hospitals, and security for both the tourists and the people of the community. This will increase the extent of tourist visit and revisit intention and thereby bring about the improvement on the government internal generating income and the personal income of the residents of the community.

(b) Community approached mechanism: A community approach in tourism has improved the economic development of both the government and the host community and thereby helping to satisfied the tourists for a revisit intention.

(c) Encouragement of Private Participation: There should be encouragement of public partnership with private individuals (PPP) in promoting tourism development in Becheeve community in Obanliku Local Government, Cross River State. Furthermore, the Cross River State Tourism Board should seek and encourage private investors and organizations towards proper management of the Obudu Mountain and Resort Ecolodge. This paper recommends a partnership between private bodies and the government in order to develop the Ecolodge and subsequently the tourism sector in the Cross River State.

(d) Community Enlightenment: The community views the tourism business as the sole responsibility of the government and as such do not participate much in it. The community should be meant to understand the potentials of tourism industry and must be encouraged to contribute their quota to the industry by interpreting their languages without being reluctant, proper handling of the implementation of their norms and tradition without abusing the fundamental rights of the tourists, demonstrating of friendliness and harmonious relationship. The Artisans must be educated and enlighten to upgrade their trade to meet the needs of the tourists. The host community must be enlightened on a regular based on the usefulness to be hospitable and polite to tourists.

(e) Service Providers should improve their Network Coverage/Service in the Community. Network. From my personal observation, its only MTN that's working on a slow paste, one has to climb the mountain to assess GLO network, others like Airtel, Etisalat were not founded. Hence, the coverage was just too bad. If good network is available in the entire location of the community, it will enable tourists to give instant information to family/friends about his/her where-about and to let the world have a feel of the experience of Obudu Mountain and Resorts.

(f) Provision of Sufficient Ecolodge facilities: This will 
increase the present carrying capacity to accommodate more ecotourists and offer the residents of the community the advantage of additional job opportunities and thereby reducing anthropogenic activities and other antienvironmental activities in the community.

Suggestions for Further Study

From my findings, I discovered there should be a further study to ascertain the degree of tourist satisfaction considering the tariff charged on the Ecolodge and the little carrying capacity of the Ecolodge as founded in Obudu Mountain and Resort in Becheeve community of Obanliku Local Government of Cross River State, Nigeria.

\section{References}

[1] Lim, C. (1997). Review of international tourism demand models. Annals of Tourism Research. 24: 835-849.

[2] Briguglio, L., Archer, B., Jafari, J., \& Wall, G. (1996). Sustainable tourism in Islands and small states: Issues and policies. London: Pinter.

[3] Butler, R. (1991). Tourism, environment, and sustainable development. Environmental Conservation, 18, 2012019.10.1017/S0376892900022104.

[4] Sharpley, R. (2003). Rural tourism and sustainability - A Critique. In D. Hall, L. Roberts, \& M. Mitchell (Eds.), New directions in rural tourism (pp. 38 53). Aldershot: Ashgate Publishing Limited.

[5] Sarfaraz Hashemkhani Zolfani, Maedeh Sedaghat, Reza Maknoon \& Edmundas Kazimieras Zavadskas (2015) Sustainable tourism: a comprehensive literature review on frameworks and applications, Economic Research-Ekonomska Istraživanja, $28: \quad 1, \quad 1 \quad 30, \quad$ DOI: 10.1080/1331677X.2014.995895.

[6] Adedeji, A. Y., (2015). Effects of Ikogosi Warm spring and Waterfall on Ikogosi and Ipole Iloro Communities, Ekiti-State.

[7] Mowforth, M. \& Munt, I. (2009). Tourism and Sustainability: Development and New Tourism in The Third World. ( $3^{\text {rd }}$ ed.). Oxon: Routledge.

[8] Muhanna, E. (2016). Sustainable Tourism Development and Environmental Management for Developing Countries. Problems and Perspectives in Management, 4 (2), 14-30.

[9] UNEP (2011). Towards a Green Economy - Pathways to Sustainable Development and Poverty Eradication. A Synthesis for Policy Makers, Retrieved from http://www.unep.org/Greeneconomy/Portals/88/documents/ge r/GER_synthesis_en.pdf

[10] Brink, T., Eijs, P, Lehmann, A., Mazza, M., Ruhweza, T., \& Shine, C. (2012). Strengthening Indicators and Accounting Systems for Natural Capital. In ten Brink (ed) (2012) The Economics of Ecosystems and Biodiversity in National and International Policy Making, 107.

[11] Holiable.com (2019). Green hotels: understanding eco-labels, Retrieved https://www.holiable.com/news/understanding/eco-hotels/

[12] ECO-RESORTS (2010). How to Choose an Ecolodge. Retrieved from https://www.ecotourism.org/news/ties- announces-ecotourism-principles-revision.

[13] EC, European Commission (2012). European Commission's water Blueprint. Retrieved from http://ec.europa.eu/ environment/water/blueprint/index_en.htm.

[14] Gibson, R. B. (2011). Specification of sustainability-based environmental assessment decision criteria and implications for determining "significance" in environmental assessment. University of British Columbia.

[15] Harris, R., \& Leiper, N. (2001). Sustainable Tourism. An Australian Perspective. Oxford: Butterworth Heinemann.

[16] Kiper, T. (2013). Role of Ecotourism in Sustainable Development (chapter 31). Namık Kemal University, Faculty of Fine Arts, Design and Architect, Department of Landscape Architecture, Turkey. Retrieved from http://cdn.intechopen.com/pdfs/45414/InTechRole_of_ecotourism_in_sustainable_development.pdf.

[17] UNEPCCT (United Nations Environmental Program Climate and Tourism) (2008). Tourism Highlights: 2008 Edition. Retrieved from https://www.eunwto.org/doi/book/10.18111/9789284413591.

[18] Gossling, S., Daniel S., \& Michael, C. M. (2012). International Tourism and Climate Change. London and New York, Routledge, 464. https://doi.org/10.1080/09669582.2013.820889.

[19] The International Ecotourism Society (2015). TIES Announces Ecotourism Principles Revision. Retrieved from https://www.ecotourism.org/new/tiesannounces-ecotourismprinciples-revision.

[20] Rockström, J., Steffen, W., Noone, K., \& Persson, A. (2009). A safe operating space for humanity. Nature, 461; 472-475. Retrieved from https://www.nature.com/articles/461472a

[21] Brink, T., Lutchman, P., Bassi, I., Speck, S., Sheavly, S., Register, K. \& Woolaway, C. (2011). Guidelines on the Use of Market-Based Instruments to Address the Problem of Marine Litter. Institute for European Environmental Policy (IEEP), Brussels and Sheavly Consultants, Virginia, US.

[22] Travel \& Tourism (2016). Economic impact reports. Retrieved from https://wttc.org/Research/Economic-Impact.

[23] IUCN Business and Biodiversity Programme, (2012). Siting and Design of Hotels and Resorts. Principles and Case Studies for Biodiversity Conservation. Gland. Retrieved from https://portals.iucn.org/library/efiles/documents/2021-03.pdf.

[24] Gansky, L. (2010). The Mesh: Why the Future of Business is Sharing. New York, NY: Portfolio Penguin.

[25] Botsman, R. \& Rogers, R., (2011). What's Mine is Yours: The Rise of Collaborative Consumption. New York, NY: Harper Business.

[26] Walsh, B. (2011). Today's smart choice: Don't own. Share. Time. Retrieved from http://content.time.com/time/specials/packages/article/0,28804 ,2059521_2059717_2059710,00.html.

[27] Awe, O., (2020). The landscape of Obudu Mountain and Resorts. Retrieved from https://storymaps.arcgis.com/stories/1067b33cf6a84fe0a29c97 9e692e6ada. 